\title{
Comparison of Oxiplex and Gore-Tex effectivity in an experimental peridural
} fibrosis model

\author{
G. Kurt; B. Cemil; B. Celik**; E. Durdag; O. Erdem* and N. Ceviker
}

Departments of Neurosurgery and Pathology*. Gazi University School of Medicine. Ankara. Turkey. Department of Neurosurgery**. Guven Hospital. Ankara. Turkey.

Summary

Objective. The authors conducted a study to compare the effectiveness of Oxiplex and Gore-tex in preventing postlaminectomy peridural fibrosis in rats. Peridural fibrosis is a common cause of pain in patients undergoing spinal surgery. To prevent scar formation numerous materials and methods have been employed such as non steroidal anti-inflammatory drugs (NSAIDs), Gelfoam, Oxiplex, Gore-tex, carboxymethil cellulose, Adcon-L, autogenous adipose grefting, mitomisin, and radiotherapy have been investigating for a long time, but only moderate success has been obtained.

Methods. Laminectomies were performed at the fourth lumbar vertebra (L-4) in 30 rats. Oxiplex or Gore-Tex was applied over the dura mater with the aim to perform a blinded evaluation of their effects. In the control group, only a L-4 laminectomy was performed. Animals were sacrificed 28 days after the surgical procedure. The extent of peridural fibrosis was evaluated on spine specimens by histological analysis.

Results. Both groups of animals treated with either Oxiplex or Gore-Tex showed a significant reduction in the degree of peridural fibrosis as compared to the control group. However no significant difference in the prevention of peridural fibrosis was observed between the Oxiplex and Gore-Tex groups.

Conclusions. This experimental model has shown that Oxiplex and Gore-Tex are effective methods to prevent peridural fibrosis and dural adhesions at the postlaminectomy areas.

KEY WORDS: Peridural fibrosis. Oxiplex. Gore-Tex. Failed back syndrome.

Comparación entre la eficacia del Oxiplex y del GoreTex en un modelo experimental de fibrosis peridural

Recibido: 29-03-08. Aceptado: 1-09-08
Resumen

Objetivo. Los autores realizaron un estudio para comparar la eficacia de Oxiplex y Gore-tex en la prevención de fibrosis peridural tras laminectomías en ratas. La fibrosis peridural es una causa común de dolor en pacientes sometidos a cirugía de la columna vertebral. Para evitar la formación de cicatriz, se han empleado numerosos materiales y métodos como los antiinflamatorios no esteroideos (AINE), Gelfoam, Oxiplex, Gore-tex, carboxymethil celulosa, Adcon-L, injertos de grasa antóloga, mitomicina o la radioterapia, pero sólo se ha obtenido resultados exitosos en pocas ocasiones.

Métodos. Se realizaron laminectomías en la cuarta vértebra lumbar (L-4) en 30 ratas. Se aplicaron Oxiplex o Gore-Tex sobre la duramadre con el objetivo de realizar una evaluación ciega de sus efectos. En el grupo control, sólo se realizó la laminectomía L4. Los animales fueron sacrificados 28 días después de la intervención quirúrgica. El grado de fibrosis peridural se evaluó sobre la columna vertebral de especímenes por análisis histológico.

Resultados. Ambos grupos de animales tratados con Oxiplex o Gore-Tex mostraron una reducción significativa en el grado de fibrosis peridural en comparación con el grupo control. Sin embargo, ninguna diferencia significativa en la prevención de la fibrosis peridural se observó entre los grupos de Oxiplex y Gore-Tex.

Conclusiones. Este modelo experimental ha demostrado que Oxiplex y Gore-Tex son métodos eficaces para prevenir la fibrosis peridural y adherencias en la duramadre tras laminectomías.

PALABRAS CLAVE: Fibrosis peridural. Oxiplex. GoreTex. Síndrome de la Cirugía Raquídea Fracasada.

Introduction

Peridural fibrosis is a common problem after the spine surgery $^{7}$. One of the major factors contributing to the failed 
back syndrome is postoperative peridural fibrosis. Failed back syndrome is a source of difficulties in the day life activities of patients who have undergone back surgeries ${ }^{14}$. Reoperation for failed back syndrome is usually unsuccessful and might cause surgical complications ${ }^{8}$. Non steroidal anti-inflammatory drugs (NSAIDs) ${ }^{15}$, Gelfoam ${ }^{27}$, Goretex $^{22,25}$, carboxymethil cellulose ${ }^{33}$, Adcon- $\mathrm{L}^{11,21}$, autogenous adipose grefting ${ }^{13}$, mitomisin ${ }^{10}$, and radiotherapy ${ }^{12}$ have been investigated as potential treatments for the prevention of scar formation after spine surgery in the last decades. Most studies provide only a qualitative evaluation of the scar formation after laminectomy therefore it is difficult to make comparisons among the different agents.

Oxiplex is a gel like absorbable nonpyrogenic material that can be used as a mechanical barrier between neuronal substances and perineuronal tissue on spinal surgery. Different studies relating to the anti-scar effects of Oxiplex have been performed in the fields of gynecology ${ }^{37}$, general surgery $^{31}$, cardiovasculary surgery ${ }^{5}$, and neurosurgery ${ }^{32}$. The main purpose of clinical trials was testing the properties of this material as a mechanical barrier that prevents the fibrosis formation and the pain associated with it.

Gore-Tex materials are typically based on thermomechanically expanded polytetrafluoroethylene and other fluoropolymer products. They are used in a wide variety of applications such as high performance fabrics, medical implants, filter media, insulation for wires and cables, gaskets and sealants. Medical uses of Gore-Tex are still under active investigation. Most experimental studies have focused on its beneficial effects for preventing postoperative peridural fibrosis. This material has been also used in other surgical areas such as general surgery ${ }^{3}$, grafting techniques in plastic surgery ${ }^{30}$, and cardiovasculary surgery ${ }^{35}$.

Several materials have been tested as barriers to reduce the extent of peridural fibrosis ${ }^{10-13,15,25,27,32,33}$. None of the barrier materials have been universally accepted for this use $^{1}$. Oxiplex and Gore-Tex have recently been used in clinical settings as an attempt to prevent peridural fibrosis ${ }^{25,28}$. Nevertheless definite conclusions to decide whether Oxiplex or Gore-Tex is a better barrier agent to prevent the development of peridural fibrosis cannot be drawn to date, due to the lack of comparative studies in scientific literature. In this study we compare the effectiveness of Oxiplex and Gore-tex in preventing the formation of peridural fibrosis after performing a lumbar laminectomy in an animal model.

\section{Materials and methods}

Thirty male Wistar rats, each weighing 300 to $350 \mathrm{~g}$, were used in this study. Gazi University Ethics Committee approval was obtained.

Rats were sedated with intramuscular Ketamine hydrochloride $35 \mathrm{mg} / \mathrm{kg}$ (Ketalar, Eczacibası, Turkey) and xylazine $5 \mathrm{mg} / \mathrm{kg}$ (Rompun, Bayer, Germany). Before the surgical procedure, the lower back area of the rats was shaved and the operative field was sterilized with povidone. The paraspinal muscles were retracted subperiostically through a L2-S1 midline incision, and L4-L5 vertebral laminae were exposed. A total L4 laminectomy was then performed with the aid of a pneumatic drill, the ligamentum flavum and peridural fat tissue were cleared away from the surgical site. Hemostasis was obtained by using a bipolar coagulator. Rats were randomly separated into three groups:

Control group $(n=10)$ : the dura mater was irrigated with saline.

Gore-Tex group $(\mathrm{n}=10)$ : the dura mater was covered with $0.5 \times 0.5 \mathrm{~cm}$ Gore-Tex.

Oxiplex group $(\mathrm{n}=10)$ : the dura mater was covered with $0.5 \mathrm{cc}$ Oxiplex./SP gel (Fziomed, inc, USA).

Sacrification was performed on the postoperative day 28 by a lethal dose of $(150 \mathrm{mg} / \mathrm{kg})$ pentobarbital (IE Ulagay, Istanbul Turkey).

The lumbar vertebrae together with their adjacent muscles were removed en bloc. Specimens were stored in a $10 \%$ buffered formalin for a further histological examination in a week. Lumbar spine specimens were then decalcified in formic acid. After paraffin sections were obtained, each bloc was completely cut into $10-\mathrm{mm}$ sections to provide optimum visualization of the laminectomy site. Histologic sections were stained with Masson trichrome and hematoxylin and eosin. All laminectomy sections were evaluated by one pathologist who analyzes the density of fibrosis, both fibroblasts and inflammatory cell counts, arachnoidal involvement, and bone regeneration.

Peridural fibrosis was graded following the scheme designed by $\mathrm{He}$ et al. ${ }^{15}$ :

Grade 0: dura mater is free of scar tissue.

Grade 1: only thin fibrous bands are observed between the scar tissue and dura mater.

Grade 2: continuous adherence is observed in less than two thirds of the bone defect.

Grade 3: scar tissue adherence is large, affecting more than two thirds of the bone defect, or the adherence extended to the nerve tissue.

Fibroblasts and the inflammatory cell counts were also evaluated, following the classification by Hinton and Warejka et al. ${ }^{16}$ :

Grade 1: 100 or fewer cells in every region at 400 times magnification.

Grade 2: 100-150 cells in every region at 400 times magnification.

Grade 3: 150 or more cells in every region at 400 times magnification.

Arachnoidal involvement by the postoperative fibrosis 


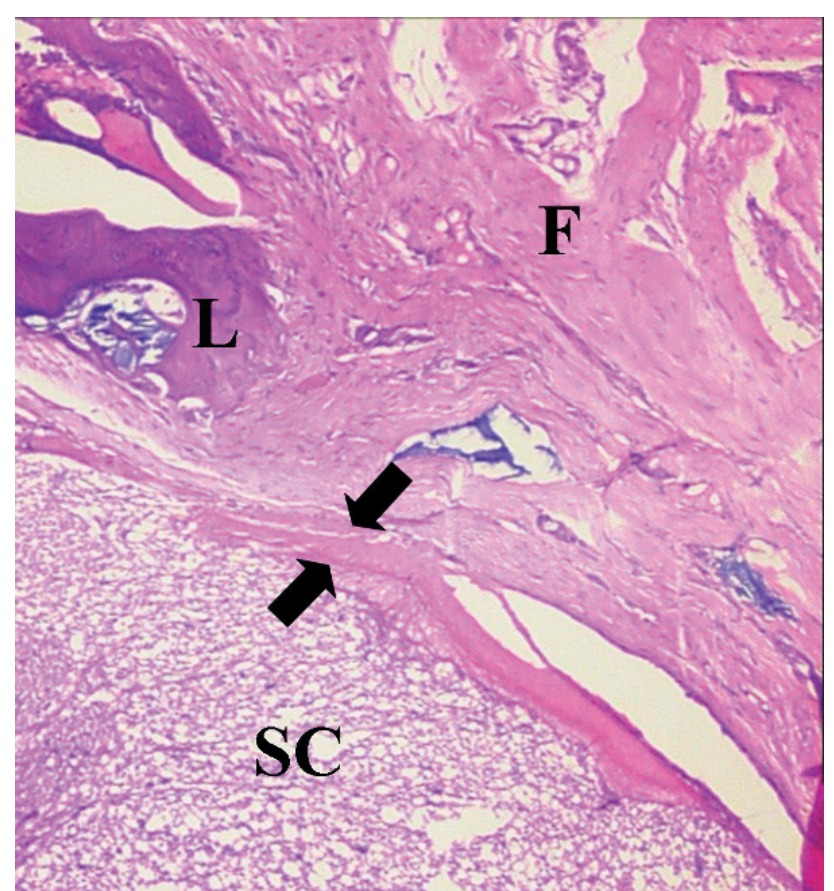

Figure 1. Grade 3 fibrosis as it is observed in the control group. The peridural fibrosis was adhered to the underlying dura mater and spinal cord. $L=$ lamina; $F=$ fibrosis; $S C=$ spinal cord; Black arrow = dura mater. Hematoxylin and Eosin, original magnification X 10.

and bone regeneration were also noted.

\section{Statistical analysis}

The grade of peridural fibrosis, fibroblasts and inflammatory cell counting, as well as the presence of arachnoid involvement and bone regeneration were the variables statistically analyzed by using standard chi square tests. $\mathrm{P}$-values greater than 0.05 being considered as statistically significant.

\section{Results}

Results regarding the degree of peridural fibrosis, and fibroblasts and inflammatory cell counting as observed in the histological analysis of the specimens are shown in Table 1. A Grade 3 peridural fibrosis was found in all the spine axial sections of rabbits belonging to the control group after staining with Masson trichrome (Fig. 1). In the Oxiplex group, a Grade 1 peridural fibrosis was demonstrated in four rats (Fig. 2) and a Grade 2 peridural fibrosis was observed in the remnant six rats. In the gore-tex group, a Grade 1 peridural fibrosis was demonstrated in eight rats (Fig. 3), a Grade 2 peridural fibrosis in one rat, and finally a Grade 3 peridural fibrosis in the remnant animal. Significant differences regarding the degree of peridural fibrosis,

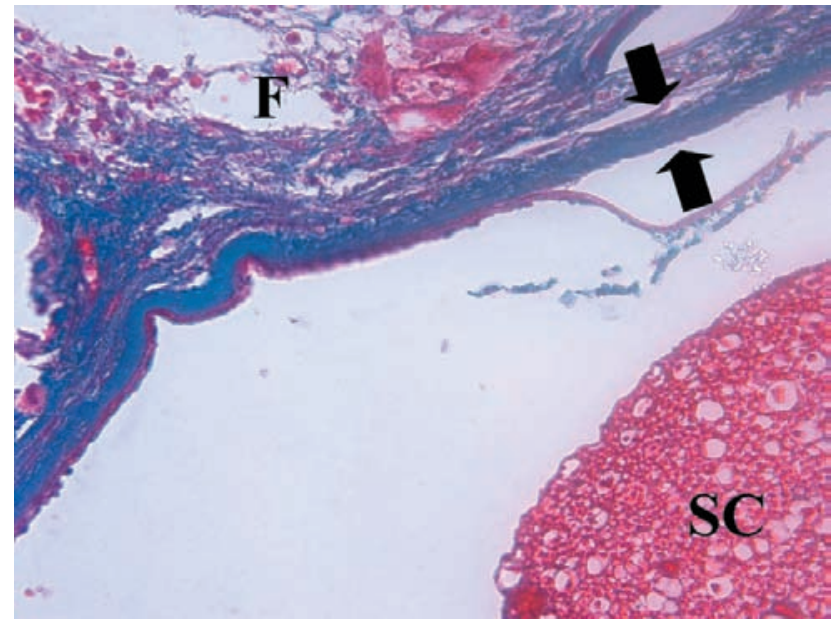

Figure 2. Grade 1 fibrosis as it is observed in the Oxiplex group. No direct contact between the underlying spinal cord and the peridural fibrosis tissue is evident. $F=$ fibrosis; $S C=$ spinal cord; Black arrow = dura mater Masson trichrome, original magnification X 40.

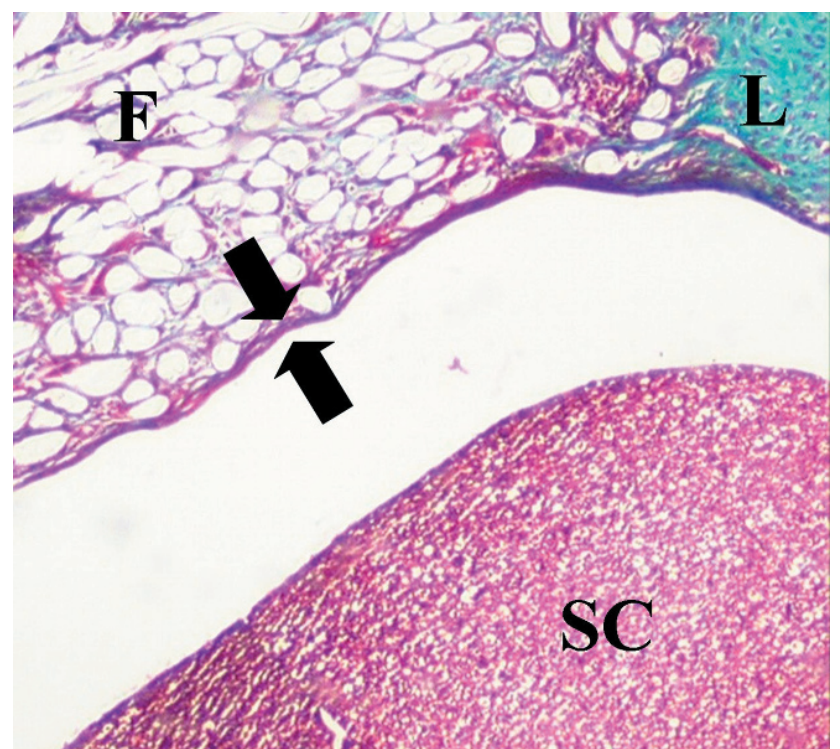

Figure 3. Grade 1 fibrosis as it is observed in the Gore-tex group. No direct contact between the underlying spinal cord and the peridural fibrosis is evident. $L=$ lamina; $F=$ fibrosis; $S C=$ spinal cord; Black arrow $=$ dura mater Masson trichrome, original magnification X 10.

the fibroblasts count, and the inflammatory cell count between the group of Oxiplex and the group of Gore-Tex were not found $(\mathrm{p}>0.05)$. Conversely, there were significant differences in the peridural fibrosis grades, in the fibroblasts count, and the inflammatory cell count between both experimental groups and the control groups $(p<0.05)$. Results of the arachnoidal involvement and bone regeneration are shown in Table 2. When the arachnoidal involvement was evaluated, statistically significant differences were found 
Table 1

Comparative results of the peridural fibrosis grades, the fibroblasts count, and the inflammatory cell count as observed in both experimental groups and control group

\begin{tabular}{|l|c|c|c|c|}
\hline \multirow{2}{*}{ Group \& Grades } & \multicolumn{3}{|c|}{ No. of Rats } \\
\cline { 3 - 5 } & Grade 1 & Peridural Fibrosis & Fibroblasts Count & Inflammatory Cell Count \\
\hline \multirow{3}{*}{ Control } & Grade 2 & - & - & - \\
\cline { 2 - 5 } & Grade 3 & 10 & - & 6 \\
\hline \multirow{3}{*}{ Oxiplex } & Grade 1 & 4 & 5 & 10 \\
\cline { 2 - 5 } & Grade 2 & 6 & 5 & - \\
\hline \multirow{3}{*}{ Gore-tex } & Grade 3 & - & - & - \\
\cline { 2 - 5 } & Grade 1 & 8 & 8 & 2 \\
\cline { 2 - 5 } & Grade 2 & 1 & 2 & 1 \\
\hline
\end{tabular}

Table 2

Comparative results of the arachnoidal involvement and bone regeneration as observed in both experimental groups and control group

\begin{tabular}{|c|c|c|c|}
\hline \multirow{2}{*}{\multicolumn{2}{|c|}{}} & \multicolumn{2}{c|}{ No. of Rats } \\
\cline { 3 - 4 } Group \& Results & Yes & 10 & Brachnoidal Involvement \\
\hline \multirow{2}{*}{ Control } & No & - & 2 \\
\cline { 2 - 4 } & Yes & 5 & 6 \\
\hline \multirow{2}{*}{ Oxiplex } & No & 5 & 4 \\
\cline { 2 - 4 } & Yes & 1 & 7 \\
\hline \multirow{2}{*}{ Gore-tex } & No & 9 & 3 \\
\hline
\end{tabular}

between both experimental groups and the control group ( $p<0.05)$. In addition, a statistical significant difference was found between the Gore-tex and the Oxiplex groups, with the former showing less arachnoidal involvement. No statistical significant difference in the degree of bone regeneration was found between both experimental groups and the control group $(\mathrm{p}>0.05)$.

\section{Discussion}

Failed-back syndrome is characterized by a severe, chronic, and disabling pain occurring in a patient after any surgical procedure of laminectomy or discetomy. Furthermore, Failed-back syndrome is generally resistant to physiotherapy or pharmacological treatment ${ }^{23}$.

There is not effective medical or surgical therapy for peridural fibrosis nowadays. With the aim of preventing postoperative peridural fibrosis several methods have been used such as anti-inflammatory medications, surgical technique variations, several biologic and synthetic materials including free fat graft, Avitene and Gelfoam, Silastic, and polylactic acid most of them yielding unsuccessful results. The rationale for their use was the interposition of an effective barrier which prevents the development of tight adherences between the dura mater and the dense fibrotic scar originated at the inner surface of the paravertebral musculature ${ }^{34}$.

Expanded Gore-Tex has been used effectively and safely for multiple clinical applications in several surgical areas, including cardiac surgery ${ }^{18}$, vascular surgery ${ }^{26}$, plastic surgery ${ }^{29}$, soft-tissue repair ${ }^{4}$, gynaecology ${ }^{6}$, and neurosurgery ${ }^{17,36}$. Gore-Tex membranes have been used 


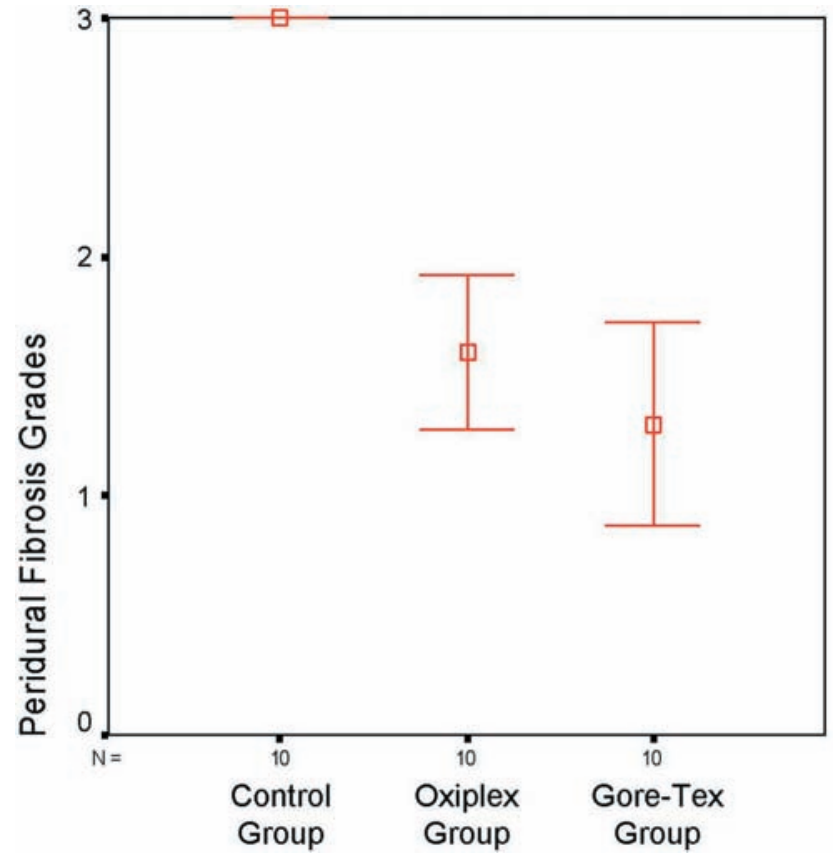

Figure 4. Box-plot graph demonstrating the differences in the degree of peridural fibrosis showed by both experimental groups and control group. Statistically significant differences between experimental groups and control group $(p>0.05)$ was observed. However, no statistically signifcant difference was seen between the Oxiplex and Gore-Tex groups.

in spine surgery with a function as a barrier to minimize adhesions in several parts of the body. In 1995, DiFazio et al. ${ }^{9}$ described a comparative study of free fat grafts, silastic sheeting, polytetrafluoroethylene membrane, and no material used for interposition in a canine model of postlaminectomy peridural fibrosis. Lladó et al. ${ }^{25}$ routinely implanted a polytetrafluoroethylene membrane in all patients undergoing a decompression operation of the lumbar spine in order to limit the development of peridural fibrosis. In a clinical trial, polytetrafluoroethylene membranes reduced postmyomectomy adhesion formation ${ }^{2}$. The peridural scar was significantly less dense in sites in which the polytetrafluoroethylene membrane had been implanted than in the other sites.

Oxiplex gel is formed by polyethilenoxide and carboxymethil cellulose. Both polyethilenoxide and carboxymethil cellulose are known to reduce adhesions and fibrotic scarring that form after surgery ${ }^{20,31}$. Calcium chloride inducing ionic cross-links is added to the formulation to create stronger interaction between the components. This modification prolongs the permanence of the product in the body because carboxymethil cellulose is otherwise rapidly resorbed ${ }^{19,24}$. Previous studies using Oxiplex have shown a significant reduction in the degree of postoperative peridural fibrosis ${ }^{32}$. In our study reabsorption of Oxiplex was observed during
4 weeks. This study has shown that Oxiplex constitutes a good physical barrier which reduces peridural fibrosis.

In this study an investigation was carried out to test which agent significantly reduces the extent of peridural fibrosis after laminectomy and prevents the consequent adhesion of this tissue to the dura mater. When the peridural fibrosis, the fibroblast density, and the inflammatory cell density results were assessed, no significant differences regarding these parameters were found between the Oxiplex and the GoreTex groups. It was remarkable that the peridural fibrosis was decreased in both experimental groups as compared with the control group. This difference was found to be meaningful statistically. Interestingly, bone regeneration results did not show any statistically significance between both experimental groups and control group.

In our study, the use of both Gore-Tex and Oxiplex caused minimal tissue reactivity, a negligible immunogenicity, and no apparent systemic toxicity. The results of the present study showed that both products have been safe and well tolerated in this animal model. In addition, both products significantly reduce the formation of fibrotic tissue, preventing the contact of this tissue with the underlying dura mater. Histological assessment of the efficacy of Gore-Tex and Oxiplex in preventing direct adhesions between the overlaying peridural fibrosis and the underlying dura mater and neural elements revealed that both materials are highly successful. Nevertheless Gore-Tex induced less arachnoidal adhesion than Oxiplex. When the sites of implantation were evaluated in both experimental groups, the soft tissues appeared to be well healed at the time the specimen was killed. Microscopic evaluation of tissue showed no evidence of infection or chronic inflammation. In addition, in the majority of laminectomies, the scar tissue appeared less dense with fewer fibroblasts, and the scar tissue was not in direct contact with the underlying dura mater.

\section{Conclusion}

The results of this study have shown that Oxiplex and Gore-Tex share a similar barrier effect. Both products successfully prevent the formation of peridural fibrosis in an experimental model of laminectomy. Both Oxiplex and Gore-Tex can be used on peridural fibrosis safely. Nevertheless, none of these products is the perfect agent to prevent peridural fibrosis. Further studies will help to clarify better agents which could provide an optimal protection against postoperative peridural fibrosis.

\section{References}

1. Abitbol, J.J., Lincoln, T.L., Lind, B.I., et al.: Preventing postlaminectomy adhesion. A new experimental model. Spine 1994; 19: 1809-1814. 
2. An expanded polytetrafluoroethylene barrier (Gore-Tex Surgical Membrane) reduces post-myomectomy adhesion formation. The Myomectomy Adhesion Multicenter Study Group. Fertil Steril 1995; 63: 491-493.

3. Aura, T., Habib, E., Mekkaoui, M., et al.: Laparoscopic tension-free repair of anterior abdominal wall incisional and ventral hernias with an intraperitoneal Gore-Tex mesh: prospective study and review of the literature. J Laparoendosc Adv Surg Tech A 2002; 12: 263-267.

4. Bauer, J.J., Salky, B.A., Gelernt, I.M., et al.: Repair of large abdominal wall defects with expanded polytetrafluoroethylene (PTFE). Ann Surg 1987; 206: 765-769.

5. Bordenave, L., Fernandez, P., Rémy-Zolghadri, M., et al.: In vitro endothelialized ePTFE prostheses: clinical update 20 years after the first realization. Clin Hemorheol Microcirc 2005; 33: 227-234.

6. Boyers, S.P., Diamond, M.P., DeCherney, A.H.: Reduction of postoperative pelvic adhesions in the rabbit with Gore-Tex surgical membrane. Fertil Steril 1988; 49: 1066-1070.

7. Cabukoglu, C., Güven, O., Yildirim, Y., et al.: Effect of sagittal plane deformity of the lumbar spine on epidural fibrosis formation after laminectomy: an experimental study in the rat. Spine 2004; 29: 2242-2247.

8. Cruccu, G., Aziz, T.Z., Garcia-Larrea, L., et al.: EFNS guidelines on neurostimulation therapy for neuropathic pain. Eur J Neurol 2007; 14: 952-970.

9. DiFazio, F.A., Nichols, J.B., Pope, M.H., et al.: The use of expanded polytetrafluoroethylene as an interpositional membrane after lumbar laminectomy. Spine 1995; 20: 986991.

10. Dogulu, F., Kurt, G., Emmez, H., et al.: Topical mitomycin C-induced inhibition of postlaminectomy peridural fibrosis in rabbits. J Neurosurg 2003; 99: 76-79.

11. Geisler, F.H.: Prevention of peridural fibrosis: current methodologies. Neurol Res 1999; 21: 9-22.

12. Gerszten, P.C., Moossy, J.J., Flickinger, J.C., et al.: Low-dose radiotherapy for the inhibition of peridural fibrosis after reexploratory nerve root decompression for postlaminectomy syndrome. J Neurosurg 2003; 99: 271-277.

13. Görgülü, A., Simşek, O., Cobanoğlu, S., et al.: The effect of epidural free fat graft on the outcome of lumbar disc surgery. Neurosurg Rev 2004; 27: 181-184.

14. Guyer, R.D., Patterson, M., Ohnmeiss, D.D.: Failed back surgery syndrome: diagnostic evaluation. J Am Acad Orthop Surg 2006; 14: 534-543.

15. He, Y., Revel, M., Loty, B.: A quantitative model of post-laminectomy scar formation. Effects of a nonsteroidal anti-inflammatory drug. Spine 1995; 20: 557-563.

16. Hinton, J.L. Jr., Warejcka, D.J., Mei, Y., et al.: Inhibition of epidural scar formation after lumbar laminectomy in the rat. Spine 1995; 20: 564-570.

17. Inoue, H.K., Kobayashi, S., Ohbayashi, K., et al.:
Treatment and prevention of tethered and retethered spinal cord using a Gore-Tex surgical membrane. J Neurosurg 1994; 80: 689-693.

18. Jacobs, J.P., Iyer, R.S., Weston, J.S., et al.: Expanded PTFE membrane to prevent cardiac injury during resternotomy for congenital heart disease. Ann Thorac Surg 1996; 62: 1778-1782.

19. Kim, K.D., Wang, J.C., Robertson, D.P., et al.: Reduction of radiculopathy and pain with Oxiplex/SP gel after laminectomy, laminotomy, and discectomy: a pilot clinical study. Spine 2003; 28: 1080-1087.

20. Kitano, T., Zerwekh, J.E., Edwards, M.L., et al.: Viscous carboxymethylcellulose in the prevention of epidural scar formation. Spine 1991; 16: 820-823.

21. Kurt, G., Aytar, M.H., Doğulu, F., et al.: A comparison of the local effectiveness of mitomycin $\mathrm{C}$, aprotinin, and Adcon-L in experimental peridural fibrosis. Surg Neurol 2008; 70: 608-613.

22. Kurt, G., Celik, B., Cemil, B., et al.: A comparison of the effectiveness of waxed paper and gore-tex on the minimally invasive epidural fibrosis model. J Spinal Disord Tech 2009; 22: 49-51.

23. Lee, J.Y., Stenzel, W., Impekoven, P., et al.: The effect of mitomycin $\mathrm{C}$ in reducing epidural fibrosis after lumbar laminectomy in rats. J Neurosurg Spine 2006; 5: 53-60.

24. Liu, L.S., Berg, R.A.: Adhesion barriers of carboxymethylcellulose and polyethylene oxide composite gels. J Biomed Mater Res 2002; 63: 326-332.

25. Lladó, A., Guimerá, J., Garcia, F., et al.: Expanded polytetrafluoroethylene membrane for the prevention of peridural fibrosis after spinal surgery: an experimental study. Eur Spine J 1999; 8: 138-143.

26. Lord, R.S., Raj, T.B., Stary, D.L., et al.: Comparison of saphenous vein patch, polytetrafluoroethylene patch, and direct arteriotomy closure after carotid endarterectomy. Part I. Perioperative results. J Vasc Surg 1989; 9: 521-529.

27. MacKay, M.A., Fischgrund, J.S., Herkowitz, H.N., et al.: The effect of interposition membrane on the outcome of lumbar laminectomy and discectomy. Spine 1995; 20: 17931796.

28. Mastronardi, L., Pappagallo, M., Tatta, C.: The Oxiplex/SP gel-morphine compound after lumbar microdiscectomy in the management of postoperative pain. Report of 20 cases. Surg Neurol 2005; 64: 75-78.

29. Mole, B.: The use of Gore-Tex implants in aesthetic surgery of the face. Plast Reconstr Surg 1992; 90: 200-206.

30. Niamtu, J. $3^{\text {rd }}:$ Advanta ePTFE facial implants in cosmetic facial surgery. J Oral Maxillofac Surg 2006; 64: 543549.

31. Rodgers, K.E., Robertson, J.T., Espinoza, T., et al.: Reduction of epidural fibrosis in lumbar surgery with Oxiplex adhesion barriers of carboxymethylcellulose and polyethylene oxide. Spine J 2003; 3: 277-283. 
32. Rodgers, K.E., Schwartz, H.E., Roda, N., et al.: Effect of oxiplex* films (PEO/CMC) on adhesion formation and reformation in rabbit models and on peritoneal infection in a rat model. Fertil Steril 2000; 73: 831-838.

33. Sun, K., Jiang, C., Lu, D.: [Prevention of peridural fibrosis and adhesion after laminectomy: an experimental study in rats] Zhonghua Wai Ke Za Zhi 1996; 34: 339-343.

34. Temel, S.G., Ozturk, C., Temiz, A., et al.: A new material for prevention of epidural fibrosis after laminectomy: oxidized regenerated cellulose (interceed), an absorbable barrier. J Spinal Disord Tech 2006; 19: 270-275.

35. Wang, X., Lin, P., Yao, Q., et al.: Development of small-diameter vascular grafts. World J Surg 2007; 31: 682689.

36. Yamagata, S., Goto, K., Oda, Y., et al.: Clinical expe- rience with expanded polytetrafluoroethylene sheet used as an artificial dura mater. Neurol Med Chir (Tokyo) 1993; 33: 582585 .

37. Young, P., Johns, A., Templeman, C., et al.: Reduction of postoperative adhesions after laparoscopic gynecological surgery with Oxiplex/AP Gel: a pilot study. Fertil Steril 2005; 84: $1450-1456$.

Kurt, G.; Cemil, B. Celik, B.; Durdag, E.; Erdem, O.; Ceviker, N.: Comparison of Oxiplex and Gore-Tex effectivity in an experimental peridural fibrosis model. Neurocirugía 2009; 20: 360-366.

Corresponding author: Berker Cemil. Department of Neurosurgery. Gazi University School of Medicine. Ankara. Turkey. 